\title{
RAZLIKE U PROCENI ZADOVOLJSTVA ŽIVOTOM IZMEĐU OSOBA KOJE IMAJU I KOJE NEMAJU ČLANA PORODICE KOME JE POTREBA POSEBNA NEGA ${ }^{23}$
}

\begin{abstract}
Abstrakt
Procena zadovoljstva životom je važan pokazatelj mentalnog zdravlja. U porodicama u kojima je jedan član oboleo, ili mu je potrebna pojačana nega i briga, mnogi parametri mentalnog zdravlja mogu opadati, pa i zadovoljstvo životom. U skladu sa tim sprovedeno je istraživanje s ciljem da se istraži uloga kvaliteta braka, zadovoljstva poslom, altruizma, obrazovanja, uzrasta i pola u zadovoljstvu životom kod osoba koje imaju člana porodice kome je potrebna posebna nega ili dodatna podrška $(N=98)$ i kod osoba koje nemaju takvog člana porodice $(N=793)$. Od instrumenata u istraživanju primenjena je kraća DAS skala, zatim kombinacija skale Altruizma i Alzam skale. Zadovoljstvo životom i zadovoljstvo poslom procenjeni su na desetostepenoj skali. Svi učesnici su bili u braku ili u partnerskoj vezi u vreme ispitivanja. Utvrđeno je da postoji značajna razlika u zadovoljstvu životom između dve grupe ispitanika - niži nivo zadovoljstva životom utvrđen je u grupi ispitanika koja ima člana porodice kome je potrebna pomoć. Značajni prediktori zadovoljstva životom u prvoj grupi ispitanika su zadovoljstvo poslom i rizici za stabilnost braka, a u drugoj grupi zadovoljstvo poslom, slaganje partnera i starost. Zadovoljstvo životom veće je kod osoba koje imaju diplomu fakulteta i/ili više škole u odnosu na one koji imaju završenu srednju školu u obe grupe ispitanika. Mada zadovoljstvo poslom predstavlja značajan prediktor zadovoljstva životom u obe grupe ispitanika, razlike se uočavaju kada je reč o aspektima kvaliteta braka - rizici za stabilnost braka umanjuju zadovoljstvo životom u grupi koja navodi da u porodici postoji član kome je potrebna dodatna pomoć, dok slaganje partnera doprinosi zadovoljstvu životom u drugoj grupi ispitanika.
\end{abstract}

Ključne reči: zadovoljstvo životom, nega člana porodice, altruizam, kvalitet braka, zadovoljstvo poslom

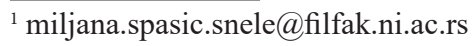

${ }^{2}$ Rad je prezentovan na naučnoj konferenciji XXVI Naučna konferencija Empirijska istraživanja $u$ psihologiji

${ }^{3}$ Rad je nastao kao deo projekta Indikatori i modeli usklađenosti uloga na poslu i u porodici Br. 179002 koje finansira Ministartsvo prosvete, nauke i tehniloškog razvoja Republike Srbije.
} 


\section{Uvod}

Zadovoljstvo životom definiše se kao kognitivna komponenta subjektivnog blagostanja (Sousa \& Lyubomirsky, 2001) i podrazumeva evaluacioni proces u kome osoba procenjuje kvalitet svoga života prema sopstvenom jedinstvenom setu kriterijuma (Pavot \& Diener, 1993, prema Bratko \& Sabol, 2006). Procene zadovoljstva životom su subjektivne i omogućuju osobi upotrebu bilo koje informacije koju smatra relevantnom za evaluaciju svog života. Iako postoji slaganje o najvažnijim komponentama "dobrog života" (npr. dobri odnosi ili pak zdravlje), pojedine osobe pripisuju različitu težinu raznim komponentama i imaju druge standarde "uspešnosti" u pojedinim domenima života. Stoga važno je ispitati globalnu procenu nečijeg života, a ne samo zadovoljstvo pojedinim aspektima (Pavot \& Diener, 1993, prema Sabol, 2006). U skladu sa tim, zadovoljstvo životom bi predstavljalo meru kognitivne procene kvaliteta ukupnih životnih okolnosti u kojima pojedinac živi (Anderson, Dubois, Leončikas, \& Sandor, 2012).

Dosadašnja istraživanja ukazala su da je zadovoljstvo životom doživljaj pod snažnim uplivom kvaliteta partnerskih i porodičnih odnosa (Eddy et al., 1998, prema Berge, Patterson, \& Rueter, 2006; Sobsey, 2004), zadovoljstva na poslu (Zhang \& Howell, 2011, prema Mafini \& Dlodlo, 2014), ali i ličnih osobenosti poput starosti (Baird, Lucas, \& Donnellan, 2010; Chen, 2001; Freund \& Baltes, 1998; Prenda \& Lachman, 2001), pola (Batz-Barbarich, Tay, Kuykendall, \& Cheund, 2018; Blanchflower \& Oswald, 2004; Pinquart \& Sörensen, 2001; Vasić, Šarčević i Trogrlić, 2011), obrazovanja (Nikolaev, 2018; Shields \& Wooden, 2003). Važnost prepoznavanja činioca koji doprinose ili umanjuju zadovoljstvo životom osobe posebno dolazi do izražaja u specifičnim situacijama, a jedna od njih jeste i kada je jednom od članova porodice potreba dodatna podrška ili nega. Imajući na umu da porodica i posao predstavljaju dva važna aspekta života odrasle osobe (Hedrih, 2013), odlučili smo da ispitamo njihovu ulogu u zadovoljstvu životom osoba koje navode da u porodici imaju člana kome je potrebna dodatna briga i nega i onih koji navode da nemaju. Kako su dosadašnja saznanja ukazala da je zadovoljstvo životom povezano i sa polom, starošću, nivoom obrazovanja, što se može videti na osnovu prethodno navedenih istraživanja, odlučili smo da ispitamo i njihov udeo u zadovoljstvu životom navedenih grupa ispitanika.

\section{Zadovoljstvo životom u kontekstu brige o članu porodice}

Porodica se može razumeti kao sistem koji prolazi kroz određene faze svog razvoja, obeležene specifičnim razvojnim zadacima (Milojković, Srna i Mićović, 1997). Prelazak iz jedne u drugu fazu životnog ciklusa zahteva određena prilagođavanja i promene što je praćeno izvesnim nivoom stresa, koji opada sa uspostavljanjem homeostaze. Ipak, ponekad u porodici mogu nastupiti razvojno neočekivane okolnosti koje dodatno inteziviraju nivo stresa i otežavaju uspostavljanje homeostaze. Prisustvo člana porodice kome je potrebna dodatna nega i briga u literaturi se određuje kao nevoljne krize koje su uglavnom vezane za nepredvidive neprijatne i teške životne događaje (Goldner Vukov, 1988). Ovakve porodice opterećene su dodatnim stresorima koji izla- 
ze van okvira razvojno očekivanih (Mitić, 1997). Porodica se susreće sa neočekivanim izazovima čije savladavanje iz različitih razloga (svesnih i nesvesnih očekivanja, želja, ideala, osobina članova porodice) može biti otežano, a potreba za negom ili dodatnom podrškom može biti u različitoj meri ispoljena (npr. pomoć u održavanju lične higijene, hranjanju, pomoć u kućnim poslovima, finansijska ili neka druga materijalna pomoć). Stoga, odrasli koji neguje ostarelog roditelja, ili mlađeg bliskog srodnika može biti iscrpljen fizički, emocionalno i finansijski, ili se naći u kompleksnom konfliktu uloga, a sukob radne, roditeljske i bračne uloge stvara dodatno osećanje preopterećenosti (Mitić, 1997; Čudina-Obradović i Obradović, 2006).

Na nekvalitetne odnose između člana porodice koji prima negu i člana porodice koji je pruža mogu delovati osobine onoga koji pruža pomoć, poput depresivnosti i bespomoćnosti, ali i osećaj zarobljenosti i pasivnosti ostalih članova porodice (Pinquart \& Sörensen, 2003; Čudina-Obradović i Obradović, 2006). Povećan napor usled nege, brige, pojačane potrebe za podrškom člana porodice, s jedne strane, umanjuje zadovoljstvo životom, a, s druge, napor da se pomogne ili olakša svojim voljenima, povećava samopoštovanje (Čudina-Obradović i Obradović, 2006). Veća bliskost i emocionlna poveznaost sa članom porodice kome je nega i dodatna podrška potrebna (ostareli roditelj ili dete), smanjuje opterećenost i nepoželjne posledice sukoba uloga (Walker, 1990, prema Čudina-Obradović i Obradović, 2006). Mikulincer, Šajver, Gilat i Nitzberg (Mikulincer, Shaver, Gillath, \& Nitzberg 2005) u opsežnoj studiji su dokazali da nesigurna privrženost praćena povišenom anksioznošću i izbegavanjem umanjuje brigu i altruističko ponašanje. Altruističko ponašanje prema definiciji predstavlja suprotnost isključivoj posvećenosti sopsvenoj dobrobiti i podrazumeva ponašanja usmerena na dobrobit drugih (Krebs, 1997). Štaub (Staub, 1978; prema Stojiljković 1997) ističe da vođenje računa o dobrobiti drugih ne zahteva nužno odricanje i žrtve. Doživljaj da pomažemo nekome i olakšavamo tešku situaciju može biti praćen doživljajem unutrašnjeg zadovoljstva iz mnogo razloga. Koncept altruizma je opravdano ispitivati u kontekstu procene zadovoljstva životom osoba koje u porodici imaju člana kome je potrebna nega i dodatna podrška.

\section{Uloga kvaliteta braka u zadovoljstvu životom}

Porodični odnosi spadaju u sferu života veoma značajnu za doživljaj zadovoljstva životom (Botha \& Booysen, 2014; Sari \& Dahlia, 2018). Brak i porodica predstavljaju institucije u kojima oba partnera i članovi porodice treba da dožive emocionalnu ispunjenost i adekvatan odgovor na raznovrsne afektivne potrebe (Minnotte, Pedersen, \& Mannon, 2010). S obzirom na to, porodica i kvalitet odnosa između njenih članova (Oberle, Schonert-Reichl, \& Zumbo, 2011) i karakteristike braka, poput bračne usklađenosti, predstavljaju važne faktore zdravlja i dobrobiti gotovo svake osobe (Basharpoor \& Sheykholeslami, 2015).

Podrška od strane bračnog partnera posebno je važna kada je porodica opterećena dodatnim nerazvojnim krizama poput bolesti člana porodice koji ima potrebu za negom i dodatnom podrškom (Ekas, Lickenbrock, \& Whitman, 2010). Međutim, usled nedostataka podrške ili nagomilanog stresa može doći do smanjenja bračnog 
zadovoljstva (Eddy et al., 1998; prema Berge et al., 2006; Sobsey, 2004), što se može odraziti i na opadanje zadovoljstva životom kod partnera. Otuda je važno ispitati ulogu kvaliteta braka kada je reč o zadovoljstvu životom u specifičnim porodičnim okolnostima, kada postoji član porodice kome je potrebna dodatna nega i podrška. U cilju procene kvaliteta braka/veze pošli smo od Spanierovog (Spanier, 1976) modela bračne usklađenosti, čiji je značaj od trenutka pojave potvrđen u mnogobrojnim istraživanjima (Scorsolini-Comin \& Santos, 2012; Vajda, Thege, \& Rozsa, 2017). Spanier (1976) bračnu usklađenost definiše kao ishod koji je određen nivoom problematičnih razlika u dijadi, interpesonalne tenzije i individualne anksioznosti, zadovoljstva dijadom, kohezije dijade i saglasnosti oko pitanja od značaja za funkcionisanje dijade.

\section{Odnos zadovoljstva životom i zadovoljstva poslom}

Zadovoljstvo poslom pored porodice predstavlja još jedan važan aspekt života osobe u odraslom dobu (Hedrih, 2013). Zadovoljstvo poslom može se posmatrati kao opšti stav prema radu, ili zadovoljstvo prema različitim dimenzijama posla (Bešlić i Bešlić, 2008). Zadovoljstvo poslom se obično određuje kao kognitivna, afektivna i evaluativna reakcija pojedinca na svoj posao.

Mnogi autori ukazali su da postoji visoka pozitivna korelacija između zadovoljstva poslom i zadovoljstva životom (Zhang \& Howell, 2011, prema Mafini \& Dlodlo, 2014). Odnos između ovih koncepata najčešće se sagledava iz ugla Chackovog modela prelivanja, gde se pretpostavlja da se zadovoljstvo u jednom domenu širi i na ostala područja života ukazujući na pozitivan odnos između zadovoljstva životom i poslom (Mafini \& Dlodlo, 2014). Ipak, da li zadovoljstvo poslom doprinosi zadovoljstvu životom ili se zadovoljstvo životom odražava i na profesionalni aspekt života još uvek predstavlja područje naučne debate. Rode (2004; prema Mafin \& Dlodlo, 2014) smatra da se generalno zadovoljstvo životom preliva i na posao što je u literaturi poznato i kao model odozgo-nadole (Unanue, Gomez, Cortez, Oyanedel, \& Mendiburo-Seguel, 2017). Prema ovom modelu individualne razlike i emocionalnost predstavljaju predispozicije zadovoljstva različitim apsektima života, uključujući i posao. Stoga se afektivna stanja prelivaju na nivo zadovoljstva poslom. S druge strane, zadovoljstvo poslom se može posmatrati kao antecedent generalnog zadovoljstva životom (Mafin \& Dlodlo, 2014). Ovakvo shvatanje pripada modelu odozdo-nagore, prema kome zadovoljstvo poslom predstavlja značajan indikator zadovoljstva životom, kao važan deo svakodnevnice odrasle osobe. Osobe koje uživaju u svom poslu biće zadovoljnije i svojim životom (Unanue et al., 2017). Sumirajući prethodno rečeno, čini se da je opravdanije govoriti o recipročnom odnosu, odnosno obostranom delovanju između zadovoljstva poslom i zadovoljstva životom. Ipak, u ovom istraživanju zadovoljstvo poslom tretiraćemo kao prediktor zadovoljstva životom, u skladu sa osnovnim ciljem, a to je identifikacija faktora koji su povezani sa zadovoljstvom životom ispitanika koji u porodici imaju/nemaju člana porodice kome je potrebna dodatna podrška. 


\section{Zadovoljstvo životom u kontekstu polnih razlika, starosti i obrazovanja}

Kada je reč o polnim razlikama, u pojedinim istraživanjima pokazalo se da žene imaju više skorove na dimenziji zadovoljstva životom (Blanchflower \& Oswald, 2004), dok je u nekim drugim utvrđeno da muškarci imaju veće zadovoljstvo životom (Pinquart \& Sörensen, 2001). Nedavno sprovedena metaanaliza sa preko milion ispitanika $(\mathrm{N}=1.001 .802)$ pokazala je da ne postoje polne razlike u zadovoljstvu životom (Batz-Barbarich et al., 2018), što je uočeno i u istraživanju sprovedenom u našem okruženju (Vasić i sar., 2011).

Nivo ostvarenog obrazovanja može imati važnu ulogu kada je reč o zadovoljstvu životom (Nikolaev, 2018), što i ne čudi imajući u vidu da viši nivo obrazovanja predstavlja korak bliže boljoj poslovnoj poziciji, što je uobičajeno praćeno većim materijalnim prihodima i većim zadovoljstvom poslom. Međutim, kako su visoke aspiracije uobičajeno praćene stresom, pojedini autori (Shields \& Wooden, 2003) navode da se može negativno odraziti na opšti nivo blagostanja i smanjenje zadovoljstva životom.

Mnogobrojne promene koje neminovno prate prirodan proces starenja, mogu se negativno odraziti na nivo zadovoljstva životom, na šta su ukazala i neka do sada sprovedena istraživanja (Chen, 2001; Freund \& Baltes, 1998). Međutim, Prenda i Lahmen (Prenda \& Lachman, 2001) na osnovu svojih rezultata dobijenih na uzorku ispitanika starosti između 25 i 75 godina, navode da je uzrast u pozitivnoj korelaciji sa zadovoljstvom životom, dok Bejrd, Lukas i Donelan (Baird et al., 2010), ipak, navode da tokom dugog perioda odraslog doba ne dolazi do promena u nivou zadovoljstva životom.

Oslanjajući se na prethodno navedeno cilj ovog istraživanja jeste prepoznavanje činioca koji doprinose zadovoljstvu životom kod osoba koje su navele da u njihovoj porodici postoji član kome je potrebna nega i dodatna pomoć i osoba koje navode da nemaju takvog člana. Polazeći od dosadašnjih saznanja pažnju smo usmerili na subjektivnu procenu kvaliteta bračnih odnosa i zadovoljstva poslom kao dva dominantna aspekta života kada je reč o osobama u odraslom dobu. Kako i pojedini individualni faktori imaju značajnu ulogu u zadovoljstvu životom, osvrnuli smo se i na ulogu altruizma, ali i pola, starosti i nivoa obrazovanja.

\section{Metod}

\section{Uzorak}

Uzorak istraživanja čine osobe koje su u braku ili partnerskoj vezi $(N=900)$. Od ukupnog uzorka 98 (10.9\%) ispitanika je navelo da ima u svojoj užoj porodici osobu kojoj je potrebna nega i/ili dodatna podrška (muškarci, $n=28$; žene $n=66$ ), za četiri osobe nemamo podatak o polu, ali kako bi njihovo isključivanje dodatno smanjilo uzorak ove grupe ispitanika odlučili smo da ih zadržimo u uzorku, tim pre, pošto pol nije uključen u regresione modele), dok se 793 (88.1\%) ispitanika (muškarci, $n=283$; žene $n=496$, za 14 ispitanika nemamo podatak o polu) izjasnilo da u 
njihovoj porodici nema člana kome je potrebna nega ili dodatna podrška.

Sociodemografske karakteristike uzorka ispitanika koji navode da imaju u užoj porodici osobu kojoj je potrebna nega i dodatna podrška. Prosečna starost prve grupe ispitanika je $44.08(S D=12.32)$, najmlađi ispitanik ima 20 , a najstariji 75 godina. U ovoj grupi 1 ispitanik nema završenu osnovnu školu (1\%), 3 imaju završeno osnovno obrazovanje (3.1\%), 58 srednju školu $(59.2 \%), 14$ višu $(14.3 \%)$, a 21 fakultet $(21.4 \%)$.

Sociodemografske karakteristike uzorka ispitanika koji navode da nemaju u užoj porodici osobu kojoj je potrebna nega i dodatna podrška. Prosečna starost ispitanika je $40.49(S D=12.41)$, najmlađi ispitanik ima 19, a najstariji 79 godina. U drugoj grupi 18 osobe (2.3\%) imaju završeno osnovno obrazovanje, 318 srednju školu (40.1), 116 višu (14.6\%), 319 fakultet (40.2\%), a 5 doktorat (.6\%).

\section{Varijable i instrumenti}

U cilju grupisanja uzorka s obzirom na to da li u užoj porodici imaju člana porodice kome je potrebna nega i/ili dodatna pomoć postavljeno je više pitanje, kako bi se identifikovali oni koji imaju ostarele i onemoćale roditelje, bake, deke ili bilo koga sa invaliditetom ili smetnjama i teškoćama u razvoju. Npr: „Da li je nekim članovima vaše porodice (roditelji, babe i/ili dede) usled njihovih poznih godina i/ili zdravstvenih problema koje te godine obično prate, potrebna vaša dodatna podrška, briga i nega?“" Na postavljena pitanja ispitanici su mogli da zaokruže jednu od alternativa "Da" ili "Ne". Ovim putem dobijena je generalna/uopštena informacija o tome da li je porodica opterećena dodatnim stresom usled pružanja dodatne brige ili nege o članu porodice (roditelji, babe i/ili dede) kome je ona potrebna, dok skala ne daje precizne podatke o starosti i vrsti srodstva člana porodice kome je potrebna nega ili dodatna pomoć i podrška.

Nivo zadovoljstva životom utvrđen je na osnovu pitanja: "Na skali od 1 (potpuno nezadovoljan) do 10 (potpuno zadovoljan) ocenite stepen vašeg zadovoljstva životom genealno". Spomenimo da se u dosadašnjim istraživanjima (Cheung \& Lucas, 2014) pokazalo da su jednoajtemske mere zadovoljstva životom pouzdane $i$ validne i da se mogu koristiti kao alternativa široko primenjene Skale Subjektivnog blagostanja (Diener, Emmons, \& Larsen, 1985; prema Cheung \& Lucas, 2014), pružajući empirijsku podršku za njihovu primenu, pre svega, u masovnijim istraživanjima sa obimnim baterijama upitnika.

Altruizam je meren skalom koja predstavlja kombinaciju skale Altruizma (Raboteg-Sarić, 2002) i Alzam skale (Čekrlija, Turjačanin i Puhalo, 2004). Sadrži 12 pitanja sa mogućim odgovorima na petosepenoj skali Likertovog tipa (1=uopšte se ne slažem do 5 = potpuno se slažem) ("Osećam se odlično kada sam u prilici da pomognem nekome") $(\alpha=$.93). Primenom eksplorativne faktorske analize izdvojio se jedan faktor (kumulativni procenat objašnjene varijanse prvim faktorom $=56.74$ ), a zasićenja svih ajtema u odnosu na faktor su u rasponu od .503 do .827.

Kvalitet braka je meren kraćom DAS skalom (Spanier, 1976), kojom se meri usklađenost dijade. Poseban doprinos Spaniera (1976) predstavlja Skala partnerske usklađenosti (Daydic Adjustment Scale; DAS), koja sadrži 32 ajtema na osnovu kojih 
se dobija mera ponašanja ili prilagođenosti bračnih partnera u različitim područjima bračnog života (slaganje partnera, zadovoljstvo partnerskim odnosom, kohezija para i uzajamno izražavanje osećanja). Polazeći od originalne verzije upitnika, za potrebe ovog istraživanja izdvojili smo 15 pitanja $(1=$ uopšte se ne slažem do $5=$ potpuno se slažem) koja su ostvarila visoko zasićenje u odnosu na glavni faktor u prethodnim istraživanjima (Vajda et al., 2017) i koja su procenjena kao značajni indikatori bračne usklađenosti, u konsultaciji sa ekspertom u ovoj oblasti (jedan od autora ovog rada). Primenom eksplorativne faktorske analize (svojstvena vrednost veća od jedan i scree plot) izdvojila su se tri faktora (kumulativni procenat objašnjene varijanse koji objašnjavaju tri faktora $=64.16)$ koje smo s obzirom na sadržaj pripadajućih pitanja odredili kao Slaganje partnera (,Molimo vas označite u kom stepenu se Vaš partner i Vi slažete ili ne slažete u navedenim stvarima: vođenje porodičnih finansija, izražavanje osećanja itd.”; $\alpha=.87$ ), Zadovoljstvo brakom („Koliko često se navedeni događaji dešavaju između Vašeg partnera i Vas: smejete se zajedno, itd.”; $\alpha=.82$ ) i Rizici za stabilnost braka („Koliko često pričate ili razmišljate o razvodu, odvajanju ili završetku veze?"; $\alpha=.75)$. Skala bračne usklađenosti sastoji se od šest pitanja, skala rizici za stabilnost braka od tri, a zadovoljstvo brakom od sedam pitanja.

Kada je reč o Slaganju partnera pitanja koja pripadaju ovom faktoru odnose se na saglasnost partnera kada je reč o vođenju porodičnih finansija, izražavanju osećanja, seksualnih odnosa, donošenja važnih odluka, interesovanja u slobodno vreme i donošenja odluka o karijeri. Rizici za stabilnost braka uključuju pitanja koja se odnose na učestalost razgovora ili razmišljanja o razvodu ili separaciji, napuštanju kuće jednog od partnera nakon svađe i učestalosti svađa. Zadovoljstvo brakom/vezom odnosi se na procenu ispitanika o tome koliko često smatraju da se stvari između njega/ nje i partnera odvijaju dobro, da li se poveravaju partneru, da li poljube partnera, da li se smeju zajedno, smireno diskutuju o nečemu i globalnu procenu koliko su srećni u braku.

Nivo zadovoljstva poslom utvrđen je na osnovu pitanja: „Na skali od 1 (potpuno nezadovoljan) do 10 (potpuno zadovoljan) ocenite stepen vašeg zadovoljstva poslom koji trenutno radite".

Sociodemografske varijable ispitane u istraživanju su: pol, nivo obrazovanja, starost.

\section{Rezultati}

Razmatrajući najpre pokazatelje normalnosti distribucije pokazalo se da su skjunis i kurtozis na varijabli zadovoljsto životom i zadovoljstvo poslom u rasponu + / -1. Ovakvi parametri govore o normalnoj distribuciji (Pallant, 2009). Kada je reč o skjunisu odnosno asimetriji distribucije varijabli altruizma, slaganje partnera, rizici za stabilnost braka i zadovoljstvo brakom uočavamo da su vrednosti u granicama + / - 2 što prema pojedinim autori (George \& Mallery, 2010) predstavljaju prihvatljive granične vrednosti, međutim, vrednosti kurtuozisa su iznad prihvatljivih granica. Kada govorimo o vrednostima skjunisa i kurtozisa treba imati u vidu i na- 
vode pojedinih autora da asimetričnost nema značniji uticaj na rezultate ako je uzorak razumno veliki, odnosno ukoliko ima preko 200 slučajeva (Tabachnik \& Fidell, 2007; prema Pallant, 2009).

Osnovne deskriptivne mere ispitivanih varijabli na uzorku osoba koje imaju i one koje nemaju nekog u užoj porodici kojima je potrebna nega i/ili dodatna podrška, predstavljene su u tabeli 1 i 2 .

Na osnovu Tabele 1 vidimo da su prosečni skorovi na varijablama zadovoljstvo životom, zadovoljstvo poslom, altruizma, slaganje partnera i zadovoljstvo brakom iznad empirijskog i teorijskog proseka kod ispitanika koji imaju u užoj porodici člana kome je potrebna nega i/ili dodatna podrška. Prosek varijable rizici za stabilnost braka su ispod teorijskog i emprijskog skora.

Tabela 1.

Osnovne deskriptivne mere ispitivanih varijabli na uzorku osoba koje imaju člana u užoj porodici kome je potrebna nega i/ili dodatna podrška

\begin{tabular}{lcccccccc}
\hline & $M$ & $S D$ & Min & Max & $S k$ & $S E$ & $K u$ & $S E$ \\
\hline $\begin{array}{l}\text { 1.Zadovoljstvo } \\
\text { životom }\end{array}$ & 6.80 & 2.31 & 1.00 & 10.00 & -0.50 & .25 & -0.45 & .49 \\
$\begin{array}{l}\text { 2. Zadovoljstvo } \\
\text { poslom }\end{array}$ & 6.25 & 2.74 & 1.00 & 10.00 & -0.50 & .27 & -0.67 & .53 \\
$\begin{array}{l}\text { 3. Altuizam } \\
\begin{array}{l}\text { 4. Slaganje } \\
\text { partnera }\end{array}\end{array}$ & 4.51 & 0.59 & 2.18 & 5.00 & -1.85 & .24 & 4.07 & .48 \\
$\begin{array}{l}\text { 5. Rizici za } \\
\text { stabilnost braka }\end{array}$ & 1.11 & 0.90 & 0.00 & 5.00 & 1.70 & .24 & 3.65 & .49 \\
$\begin{array}{l}\text { 6. Zadovoljstvo } \\
\text { brakom }\end{array}$ & 3.77 & 0.96 & 0.14 & 5.00 & -1.34 & .24 & 3.17 & .48 \\
\begin{tabular}{l} 
7. Starost \\
\hline
\end{tabular} & 44.08 & 12.31 & 20.00 & 75.00 & 0.14 & .24 & -0.62 & .48 \\
\hline
\end{tabular}

Napomena. $M$ - aritemtička sredina; $S D$ - standardna devijacija; Min - minimum; Max - maksimum; Sk - skjunis (asimetričnost); Ku - kurtosis (spljoštenost); $S E$ standardna greška.

U Tabeli 2 vidimo da su prosečni skorovi na varijablama zadovoljstvo životom, zadovoljstvo poslom, altruizma, slaganje partnera i zadovoljstvo brakom iznad empirijskog i teorijskog proseka na uzorku osoba koje nemaju člana u užoj porodici kome je potrebna nega i/ili dodatna podrška. Prosečna vrednost procene rizika za stabilnost braka je niska i ispod prosečne teorijske vrednosti. 
Tabela 2.

Osnovne deskriptivne mere ispitivanih varijabli na uzorku osoba koje nemaju članove u užoj porodici kojima je potrebna nega i/ili dodatna podrška

\begin{tabular}{lcccccccc}
\hline & AS & SD & Min & Max & Sk & SE & Ku & SE \\
\hline $\begin{array}{l}\text { 1.Zadovoljstvo } \\
\text { životom }\end{array}$ & 7.34 & 1.91 & 1.00 & 10.00 & -0.96 & .09 & 0.90 & .17 \\
$\begin{array}{l}\text { 2. Zadovoljstvo } \\
\text { poslom }\end{array}$ & 6.79 & 2.32 & 1.00 & 10.00 & -0.66 & .09 & -0.20 & .18 \\
$\begin{array}{l}\text { 3. Altuizam } \\
\text { 4. Slaganje partnera }\end{array}$ & 4.43 & 0.68 & 1.00 & 5.00 & -2.00 & .09 & 5.12 & .17 \\
$\begin{array}{l}\text { 5. Rizici za stabilnost } \\
\text { braka }\end{array}$ & 0.96 & 0.92 & 0.00 & 5.00 & -1.37 & .09 & 2.38 & .18 \\
$\begin{array}{l}\text { 6. Zadovoljstvo } \\
\text { brakom }\end{array}$ & 3.90 & 0.91 & 0.00 & 5.00 & 1.72 & .09 & 3.92 & .18 \\
9. Starost & 40.49 & 12.41 & 19.00 & 79.00 & 0.34 & .08 & -0.56 & .17 \\
\hline
\end{tabular}

Napomena. $M$ - aritemtička sredina; $S D$ - standardna devijacija; Min - minimum; Max - maksimum; $S k$ - skjunis (asimetričnost); Ku - kurtosis (spljoštenost); $S E$ standardna greška.

S obzirom na to da je narušena pretpostavka o jednakosti varijanse, predstavljen je odgovarajući $t$ test izračunat kada varijansa između grupa nije jednaka. Pokazalo se da postoji razlika u zadovoljstvu životom između pojedinaca koji navode da imaju člana u užoj porodici kome je potrebna nega i/ili dodatna podrška i onih koji navode da nemaju (Tabela 3). Zadovoljstvo životom je veća u drugoj grupi ispitanika.

Tabela 3 .

Razlika u zadovoljstvu životom između pojedinaca koji navode da imaju i onih koji navode da nemaju člana u užoj porodici kome je potrebna nega i dodatna podrška

\begin{tabular}{|c|c|c|c|c|c|c|}
\hline Grupa & $\begin{array}{c}M \\
(S D)\end{array}$ & $\begin{array}{c}\text { Levinov test jednakosti } \\
\text { varijanse }\end{array}$ & $p$ & $t(d f)$ & $p$ & $\eta^{2}$ \\
\hline $\begin{array}{l}\text { Sa članom porodice kome je } \\
\text { potrebna nega i dodatna podrška }\end{array}$ & $6.80(2.31)$ & & & & & \\
\hline $\begin{array}{l}\text { Bez člana porodice } \\
\text { kome je potrebna nega i dodatna } \\
\text { podrška }\end{array}$ & 7.34 (1.91) & 10.53 & .00 & $(111.47)$ & .03 & .005 \\
\hline
\end{tabular}

Napomena. $M$ - aritmetička sredina; $p$ - statistička značajnost; $t-t$ statistik, $\eta^{2}-$ eta kvadrat (mera veličine efekta).

Na osnovu Tabele 4 možemo videti da je zadovoljstvo životom na uzorku osoba koje imaju u užoj porodici člana kome je potrebna nega i/ili dodatna podrška u pozitivnoj korelaciji srednjeg inteziteta sa zadovoljstvom poslom. Zadovoljstvo životom je u niskoj korelaciji negativnog smera sa rizicima za stabilnost braka. 
Tabela 4.

Povezanost ispitivanih varijabli na uzorku osoba koje imaju člana u užoj porodici kome je potrebna nega i/ili dodatna podrška

\begin{tabular}{lcccccc}
\hline & 1 & 2 & 3 & 4 & 5 & 6 \\
\hline 1.Zadovoljstvo životom & $/$ & & & & & \\
2. Zadovoljstvo poslom & $.57^{* *}$ & & & & & \\
3. Altuizam & .03 & .13 & & & & \\
4. Slaganje partnera & .14 & -.04 & -.02 & & & \\
5. Rizici za stabilnost braka & $-.29^{* *}$ & -.12 & $-.40^{* *}$ & $-.38^{* *}$ & & \\
6. Zadovoljstvo brakom & .13 & -.05 & .17 & $.73^{* *}$ & $-.45^{* *}$ & \\
7. Starost & -.12 & -.17 & -.03 & -.08 & -.09 & -.17 \\
\hline
\end{tabular}

Napomena. ${ }^{* *}$ korelacija je značajna na nivou .01; * korelacija je značajna na nivou .05 .

Iz Tabele 5 možemo uočiti da je zadovoljstvo životom u pozitivnoj korelaciji srednjeg inteziteta sa zadovoljstvom poslom i slaganjem partnera, a u niskoj korelaciji sa zadovoljstvom brakom na uzorku osoba koje nemaju člana u užoj porodici kome je potrebna nega i dodatna podrška, a zadovoljstvo životom je u negativnoj korelaciji niskog inteziteta sa rizicima za stabilnost braka i starosti ispitanika.

Tabela 5.

Povezanost između varijabli na uzorku osoba koje nemaju člana u užoj porodici kome je potrebna nega i dodatna podrška

\begin{tabular}{lcccccc}
\hline & 1 & 2 & 3 & 4 & 5 & 6 \\
\hline 1.Zadovoljstvo životom & $/$ & & & & & \\
2. Zadovoljstvo poslom & $.46^{* *}$ & $/$ & & & & \\
3. Altuizam & .04 & .06 & $/$ & & & \\
4. Slaganje partnera & $.30^{* *}$ & $.13^{* *}$ & $.12^{* *}$ & $/$ & & \\
5. Rizici za stabilnost & $-.22^{* *}$ & $-.11^{* *}$ & $-.13^{* *}$ & $-.53^{* *}$ & $/$ & \\
braka & $.26^{* *}$ & $.12^{* *}$ & $.16^{* *}$ & $.67^{* *}$ & $-.47^{* *}$ & $/$ \\
6. Zadovoljstvo brakom & $-.14^{* *}$ & $-.08^{*}$ & .01 & $-.15^{* *}$ & $-.09^{*}$ & $-.28^{* *}$ \\
7. Starost &
\end{tabular}

Napomena. ${ }^{* *}$ korelacija je značajna na nivou $.01 ; *$ korelacija je značajna na nivou .05 .

\section{Standardna višestruka regresija}

U Tabeli 6 predstavljeni su rezultati standardne višestruke regresione analize gde je kriterijum varijabla zadovoljstvo životom, a prediktori zadovoljstvo poslom i rizici za stabilnost braka na uzorku osoba koje navode da imaju u užoj porodici člana kome je potrebna nega i/ili dodatna podrška. Model kao celina je statistički značajan $(F(2$, $73)=23.986, p<.000)$ i pokazalo se da objašnjava $38 \%$ varijanse kriterijumske varijable zadovoljstva životom. Kao značajan prediktor pozitivnog smera pokazalo se zadovoljstvo poslom, a negativnog smera rizici za stabilnost braka (Tabela 6). 
Tabela 6.

Standardna višestruka regresija - prediktor zadovoljstvo životom ispitanika koji imaju člana u užoj porodici kome je potrebna nega i/ili dodatna podrška

\begin{tabular}{lccccccc}
\hline \multicolumn{1}{c}{ Prediktori } & $\beta$ & $p$ & Tolerance & VIF & $R^{2}$ & Prilagođen $R^{2}$ & $p$ \\
\hline Zadovoljstvo poslom & .54 & .000 & .99 & 1.01 & & & \\
$\begin{array}{l}\text { Rizici za stabilnost } \\
\text { braka }\end{array}$ & -.26 & .005 & .99 & 1.01 & .39 & .38 & .000 \\
\hline
\end{tabular}

Napomena. $\beta$-standardizovani regresioni koeficijent; $p$ - statistička značajnost; Tolerance $i$ VIF - mere multikolinearnosti; $R^{2}$ - koeficijent determinacije; Prilagođen $R^{2}$ - prilagođen keoficijent determinacije.

Model gde je kriterijumska varijabla zadovoljstvo životom, a prediktori zadovoljstvo poslom, zadovoljstvo brakom, rizici za stabilnost braka, slaganje partnera na uzorku osoba koji navode da u užoj porodici nemaju člana kome je potrebna nega i/ili dodatna podrška kao celina je statistički značajan $(F(5,674)=57.15, p<.00)$ i objašnjava 29.3\% varijanse kriterijumske varijable. Kao značajni prediktori pozitivnog smera izdvojili su se zadovoljstvo poslom i slaganje partnera, a negativnog starost ispitanika (Tabela 7).

Tabela 7.

Standardna višestruka regresija - prediktor zadovoljstvo životom ispitanika koji nemaju u užoj porodici člana kome je potrebna nega i/ili dodatna podrška

\begin{tabular}{|c|c|c|c|c|c|c|c|}
\hline Prediktori & $\beta$ & $p$ & Tolerance & $V I F$ & $R^{2}$ & Prilagođen $R^{2}$ & $p$ \\
\hline Zadovoljstvo poslom & .45 & .00 & .97 & 1.03 & & & \\
\hline Slaganje partnera & .17 & .00 & .49 & 2.06 & & & \\
\hline Rizici za stabilnost braka & -.07 & .07 & .64 & 1.57 & 29.8 & 29.3 & .000 \\
\hline Zadovoljstvo brakom & .01 & .75 & .48 & 2.09 & & & \\
\hline Starost & -.09 & .01 & .84 & 1.19 & & & \\
\hline
\end{tabular}

Napomena. $\beta$-standardizovani regresioni koeficijent; $p$-statistička značajnost; Tolerance $i$ VIF - mere multikolinearnosti; $R^{2}$ - koeficijent determinacije; Prilagođen $R^{2}$ prilagođen keoficijent determinacije.

Na osnovu Tabele 8 možemo uočiti da ne postoji razlika u zadovoljstvu životom s obzirom na pol kod ispitanika koji imaju u užoj porodici člana kome je potrebna nega i/ili dodatna podrška. 
Tabela 8 .

Razlika u zadovoljstvu životom s obzirom na pol ispitanika koji imaju u užoj porodici člana kome je potrebna nega i/ili dodatna podrška

\begin{tabular}{lccccc}
\hline \multicolumn{1}{c}{ Grupa } & $M(S D)$ & $\begin{array}{c}\text { Levinov test } \\
\text { jednakosti varijanse }\end{array}$ & $p$ & $t(d f)$ & $p$ \\
\hline $\begin{array}{l}\text { Muškarci } \\
\text { Žene }\end{array}$ & $6.59(2.13)$ & 1.85 & .211 & $-.50(90)$ & .61 \\
\hline
\end{tabular}

Napomena. $M$ - aritmetička sredina; $p$ - značajnost; $t$ - t statistik.

Nisu utvrđene razlike u zadovoljstvu životom s obziorm na pol kod ispitanika koji nemaju u užoj porodici člana kome je potrebna nega i/ili dodatna podrška (Tabela 9).

Tabela 9.

Razlika u zadovoljstvu životom s obzirom na pol ispitanika koji nemaju u užoj porodici člana kome je potrebna nega i/ili dodatna podrška

\begin{tabular}{lccccc}
\hline \multicolumn{1}{c}{ Grupa } & $M(S D)$ & $\begin{array}{c}\text { Levinov test } \\
\text { jednakosti varijanse }\end{array}$ & $p$ & $t(d f)$ & $p$ \\
\hline $\begin{array}{l}\text { Muškarci } \\
\text { Žene }\end{array}$ & $7.27(1.94)$ & .132 & .717 & $-.68(772)$ & .49 \\
\hline
\end{tabular}

Napomena. $M$ - aritmetička sredina; $p$ - značajnost; $t$ - t statistik.

S obzirom na to da samo tri ispitanika koji imaju u užoj porodici člana kome je potrebna nega i/ili dodatna podrška navodi da je završilo osnovno obrazovanje, ova kategorija nije uključena u dalju analizu. Dalje, 58 ispitanika navodi da ima završenu srednju školu, 14 navodi da je završilo višu školu, a 21 fakultet ili magistraturu. U cilju provere postojanja razlike između grupa s obzirom na nivo obrazovanja, odlučili smo da ispitanike iz poslednje dve kategorije spojimo u jednu koju će činiti ispitanici koji su zavšili višu školu ili fakultet, tim pre što između ove dve grupe nisu utvrđene razlike u zadovoljstvu životom $(t(32)=.06, p=.954)$. U skladu sa tim ispitano je da li postoje razlike u zadovoljstvu životom ispitanika koji imaju u užoj porodici člana kome je potrebna nega i/ili dodatna podrška koji su završili srednju školu i onih koji su završilu višu školu/fakultet.

Na osnovu rezultata predstavljenih u Tabeli 10 uočavamo da postoji razlika s obzirom na nivo obrazovanja, pri čemu je veći stepen zadovoljstva životom uočen kod ispitanika koji su završili višu školu/fakultet. 
Tabela 10.

Razlika u zadovoljstvu životom s obzirom na nivo obrazovanja ispitanika koji imaju u užoj porodici člana kome je potrebna nega i/ili dodatna podrška

\begin{tabular}{lcccccc}
\hline \multicolumn{1}{c}{ Grupa } & $M(S D)$ & $\begin{array}{c}\text { Levinov test } \\
\text { jednakosti varijanse }\end{array}$ & $p$ & $t(d f)$ & $p$ & $\eta^{2}$ \\
\hline Srednja škola & $6.24(2.50)$ & 7.27 & .008 & $\begin{array}{c}-3.41 \\
(87.11)\end{array}$ & .001 & .11 \\
Viša škola/fakultet & $7.76(1.72)$ & 71 & & \\
\hline
\end{tabular}

Napomena. $M$ - aritmetička sredina; $p$ - značajnost; $t$ - t statistik, $\eta^{2}$ - eta kvadrat (mera veličine efekta).

U grupi ispitanika koji nemaju u užoj porodici člana kome je potrebna nega i/ili dodatna podrška 18 ispitanika navodi da ima zavšeno samo osnovno obrazovanje, a pet imaju doktorat. S obzirom na to ove kategorije nisu uključene u dalju analizu. Dalje, 318 ispitanika navodi da ima završenu srednju školu, 116 navodi da je završilo višu školu, a 319 fakultet ili magistraturu. U skladu sa tim proverili smo da li postoje razlike u zadovoljstvu životom ispitanika koji nemaju u užoj porodici člana kome je potrebna nega i/ili dodatna podrška između onih koji imaju završenu srednju školu, višu školu i fakultet. Uvidom u Tabelu 11 uočavamo da postoji razlika u stepenu izraženosti zadovoljstva životom između ispitanika koji su zavšili srednju školu, gde su utvrđeni niži prosečni skorovi u odnosu na ispitanike koji su završili višu školu, odnosno fakultet.

Tabela 11 .

Razlika u zadovoljstvu životom s obzirom na nivo obrazovanja ispitanika koji nemaju u užoj porodici člana kome je potrebna nega i/ili dodatna podrška

\begin{tabular}{lccccccc}
\hline \multicolumn{1}{c}{ Grupa } & $M(S D)$ & $\begin{array}{c}\text { Levinov test jednakosti } \\
\text { varijanse }\end{array}$ & $p$ & Welch-ov $F$ & $d f$ & $p$ & $\eta^{2}$ \\
\hline Srednja škola & $7.06(2.03)$ & & & & & & \\
Viša škola & $7.55(1.77)$ & 9.27 & .000 & 9.50 & $2 / 320.8$ & .000 & .026 \\
Fakultet & $7.41(1.86)$ & & & & & & \\
\hline
\end{tabular}

Napomena. $\mathrm{M}$ - aritmetička sredina; $\mathrm{p}$ - značajnost; Welch-ov F - F statistik ; df - stepeni slobode; $\eta^{2}$ - eta kvadrat (mera veličine efekta).

Tabela 12.

Razlika u zadovoljstvu životom s obzirom na nivo obrazovanja ispitanika koji nemaju u užoj porodici člana kome je potrebna nega i/ili dodatna podrška (post-hoc test Tukey)

\begin{tabular}{lccc}
\hline \multicolumn{1}{c}{ Grupa } & Razlika $M$ & $p$ & $S E$ \\
\hline Srednja škola & -.49 & .041 & .19 \\
Viša škola & & & \\
Srednja škola & -.64 & .000 & .15 \\
Fakultet & & & .19 \\
Viša škola & -.15 & .724 &. \\
Fakultet & &
\end{tabular}

Napomena. $M$ - aritmetička sredina; $p$ - značajnost; $S E$ - standardna greška. 


\section{Diskusija}

Jedan od ciljeva istraživanja sprovedenog 2018. godine bio je da ispita da li se razlikuje konfiguracija prediktora zadovoljstva životom (kvalitet braka, zadovoljstvo poslom, altruizam, starost) kod osoba koje imaju člana porodice kome je potrebna nega i/ili dodatna podrška i kod osoba koje navode da nemaju takvog člana.

Porodica i njena struktura, kao i određene faze životnog ciklusa porodice nameću specifične zadatke, pa shodno tome različito opterećuju porodični sistem (Milojković, Srna i Mićović, 1997). Ipak, verovatno je najteže onim porodicama koje imaju člana kome je potreba pojačana nega zbog bolesti, starosti ili invaliditeta, zbog smetnji i teškoća u razvoju, ili pripada nekoj od kategorija osetljivih grupa, što može ugroziti doživljaj blagodeti i zadovoljstva životom svim članovima porodice. Sukob radne, roditeljske i bračne uloge stvara dodatno osećanje preopterećenosti. Da povećan napor usled nege i/ili potrebe za dodatnom podrškom člana porodice (sa invaliditetom, smetnjama ili teškoćama u razvoju, osoba iz drugih marginalizovanih i osetljivih grupa) može umanjiti zadovoljstvo životom, ukazuju i rezultati našeg istraživanja. Pokazalo se da ispitanici koji navode da imaju u užoj porodici osobu kojoj je potrebna dodatna podrška, briga i nega izveštavaju o nižem zadovoljstvu životom u odnosu na one koji navode da nemaju.

Pored razlika u generalnoj proceni zadovoljstva sopstvenim životom, uočene su razlike i kada je reč o korelatima i prediktorima zadovoljstva životom između ove dve grupe. Tako, značajni korelati zadovoljstva životom na uzorku ispitanika koji imaju u užoj porodici člana kome je potrebna nega i/ili dodatna podrška jesu zadovoljstvo poslom i rizici za stabilnost braka. Dok je zadovoljstvo poslom u pozitivnoj korelaciji, rizici za stabilnost braka su u negativnoj korelaciji sa zadovoljstvom životom. S druge strane, zadovoljstvo životom je u pozitivnoj korelaciji srednjeg inteziteta sa zadovoljstvom poslom i slaganjem partnera, a u niskoj korelaciji pozitivnog smera sa zadovoljstvom brakom na uzorku ispitanika koji navode da nemaju člana u užoj porodici kome je potrebna nega i/ili dodatna podrška. Zadovoljstvo životom je u negativnoj korelaciji niskog inteziteta sa rizicima za stabilnost braka i starošću ispitanika.

Zadovoljstvo poslom daje značajan doprinos zadovoljstvu životom ispitanika koji navode da u užoj porodici imaju člana porodice kome je potrebna nega i/ili dodatna podrška. S druge strane, rizici za stabilnost braka umanjuju globalnu procenu zadovoljstva životom. Dobijeni rezultat nije iznenađujuć. Naime, brak je zajedništvo „ranjivo” iz različitih razloga. U uobičajenim okolnostima jeste pod rizikom od sloma, kako zbog karakteristika bračnih partnera, njihove prezauzetosti, uticaja sa strane, tako i faktora šireg društvenog okruženja, kao što su siromaštvo i nezaposlenost (Goldner-Vukov, 1988). Potreba za pojačanom negom i dodatnom podrškom nekom od članova porodice, može dodatno opteretiti porodični sistem koji u takvim okolnostima iscrpljuje emotivne, fizičke i materijalne resurse. Usled nedostataka porodične ili institucionalne podrške i nagomilanog stresa može doći do smanjenja bračnog zadovoljstva (Eddy et al., 1998; prema Berge et al., 2006; Sobsey, 2004), što se može 
odraziti i na opadanje zadovoljstva životom kod partnera. Osim toga mada altruzam nije povezan sa zadovoljstvom životom, on je u značajnoj negativnoj korelaciji srednjeg opsega sa rizicima za stabilnost braka kod ispitanika koji imaju člana porodice kome je potrebna nega i/ili dodatna podrška. Ukoliko je altruzam više izražen kod osoba koje neguju člana porodice, manji su rizici za stabilnost braka. U poduzorku ispitanika koji ne neguju člana porodice altruizam se pokazao značajnim za slaganje partnera, za zadovoljstvo brakom kao i za rizike za stabilnost braka. Mada su značajne, ove korelacije su niske i možemo ih pripisati i veličini uzorka. Direktno altruizam nema značaja za procenu zadovoljstva životom, ali jasno je iz dobijenih korelacija da smanjuje rizike za stabilnost braka u okolnostima većeg opterećenja porodice usled nege i/ili potrebe za dodatnom podrškom jednog od članova.

U nameri da izdvojimo značajne faktore zadovoljstva životom kod osoba koje se nalaze u specifičnoj porodičnoj situaciji usled potrebe za negom i/ili dodatnom podrškom člana porodice, kao i kod osoba koje nemaju takve članove u porodici, ispitivan je doprinos zadovoljstva poslom. Na osnovu dobijenih rezultata evidentno je da zadovoljstvo poslom predstavlja jedan od značajnih prediktora zadovoljstva životom kod obe grupe ispitanika, potvrđujući dosadašnja istraživanja (Kinicki et al., 2002; prema Mafini \& Dlodlo, 2014). Naime, posao predstavlja važan deo svakodnevince odrasle osobe, pa se može očekivati da će osobe koje uživaju u svom poslu biti zadovoljnije i svojim životom (Unanue et al., 2017). Izloženo shvatanje je u skladu sa Chack-ovim modelom prelivanja, gde se pretpostavlja da se zadovoljstvo $\mathrm{u}$ jednom domenu preliva i na ostala područja života ukazujući na pozitivan odnos između zadovoljstva životom i poslom (Mafini \& Dlodlo, 2014).

Pored zadovoljstva poslom, na uzorku osoba koje nemaju u užoj porodici člana kome je potrebna nega i/ili dodatna podrška, zadovoljstvu životom doprinosi slaganje partnera. U našem istraživanju slaganje partnera odnosi se na domene vođenja porodičnih finansija, izražavanje osećanja, participaciju u donošenju važnih odluka, interesovanjima u slobodno vreme, planiranju karijere i seksualnim afinitetima. Prema literaturi pozitivno sagledavanje braka, u čemu važnu ulogu ima i saglasnost partnera po pitanju različitih aspekata njihovog odnosa, doprinosi njihovoj pozitivnijoj evaluaciji života u celini (Scorsolini-Comin \& Santos, 2012). Spomenimo i to da se i zadovoljstvo brakom pokazalo kao jedan od značajnih korelata zadovoljstva životom, potvrđujući rezultate dosadašnjih istraživanja (Scorsolini-Comin \& Santos, 2012). Ipak, moramo da napomenemo da su dobijeni rezultati utvrđeni samo na uzorku osoba koje nemaju člana porodice kome je potrebna nega i/ili dodatna podrška.

U skladu sa nekim dosadašnjim istraživanjima (Chen, 2001; Freund \& Baltes, 1998), pokazalo se da zadovoljstvo životom opada sa godinama, međutim, to je jedino utvrđeno na uzorku osoba koje navode da u porodici nemaju člana porodice kome je potrebna dodatna nega. Ipak, treba reći da se u nekim istraživanjima pokazalo da je (Prenda \& Lachman, 2001) uzrast u pozitivnoj korelaciji sa zadovoljstvom životom, dok Bejrd i saradnici (Baird et al., 2010) ukazuju da je nivo zadovoljstva životom relativno stabilan tokom dugog perioda odraslog doba. Nekonzistentnost dobijenih rezultata može ukazati na posredstvo moderator varijabli, koje mogu biti 
metodološke prirode poput primenjenog instrumenta kojim se meri zadovoljstvo životom, ali i kulturološki faktori. U skladu sa tim smatramo da bi metaanaliza dala veliki doprinos u boljem razumevanju ove povezanosti.

Kada je reč o polnim razlikama u zadovoljstvu životom, ukazali smo na to da dosadašnji rezultati ne daju jedinstven odgovor, s obzirom na to da se u pojedinim istraživanjima pokazalo da žene imaju više skorove na dimenziji zadovoljstva životom (Blanchflower \& Oswald, 2004), a u nekim drugim pak, takav rezultat ustanovljen je na uzorku muškaraca (Pinquart \& Sörensen, 2001). U nizu istraživanja, kome pripada i naše, nisu utvrđene polne razlike u proceni zadovoljstva životom (Batz-Barbarich et al., 2018; Vasić i sar., 2011).

Pokazalo se u oba uzorka da postoji razlika u zadovoljstvu životom između ispitanika koji imaju zavšenu srednju školu, s jedne strane i ispitanika koji su završili višu školu, odnosno fakultet, s druge, a veći nivo zadovoljstva utvrđen je u grupi sa višim nivoom obrazovanja. S obzirom na to da viši nivo obrazovanja predstavlja korak bliže boljoj poslovnoj poziciji, većim materijalnim prihodima, većem zadovoljstvu poslom, boljem ugledu u društvu (Nikolaev, 2018; Sousa \& Lyubomirsky, 2001), ne iznenađuje rezultat o njegovoj ulozi u zadovoljstvu životom i to kod oba uzorka našeg istraživanja.

Ovo istraživanje prate i određeni nedostaci. Pre svega, ispitanicima je postavljeno pitanje o tome da li u njihovoj porodici postoji osoba kojoj je potrebna nega i/ili dodatna pomoć. Razdvajanje podgrupa s obzirom na vrstu nege i/ili dodatne podrške koja je potrebna članu porodice pružilo bi mogućnost dobijanja preciznijih informacija, prepoznavanja eventualnih razlika između njih, a samim tim i specifičnijeg i boljeg razumevanja faktora koji su od važnosti za zadovoljstvo životom, ali bi u tom slučaju poduzorci bili znatno manji. Pored toga, kako u našem istraživanju grupe ispitanika nisu bile ujednačene ni po veličini ni po polu, bilo bi značajno sprovesti dodatna istraživanja sa ujednačenijim grupama.

Ovo istraživanje je jedno od malobrojnih sa temom ispitivanja zadovoljstva životom osoba koje u porodici imaju člana koga treba negovati ili mu pružiti dodatnu podršku. S obzirom na to da aktivno učestvuju u brizi oko članova porodice, važno je ispitati i bolje razumeti faktore koji su povezani sa njihovim blagostanjem, ne bi li se napravio plan podrške takvim porodicama u cilju povećanja njihovog zadovoljstva životom. Stoga dobijeni rezultati mogu biti od posebne važnosti za stručnjake koji neposredno rade sa osobama kojima je potrebna dodatna podrška i njihovim članovima porodice. Saznanje da se dete ne razvija očekivanim tokom ili da ima određene smetnje ili da je do nedavno funkcionalnom članu porodice, potrebna dodatna pomoć, može predstavljati veliku krizu za porodicu koja se može odraziti na sve aspekte porodičnog života i eventualano rezultovati slamanjem bračnog sistema. Dobijeni nalazi ukazuju na to da jedan od aspekata na kome treba raditi jeste upravo jačanje bračnog saveza, jer čini se da on najviše "trpi” u specifičnim životnim okolnostima, umanjujući opšti nivo zadovoljstva životom partnera. 


\section{Zaključak}

Zadovoljstvo poslom i dimenzije kvaliteta braka imaju značajne uloge u zadovoljstvu životom u oba uzorka. Međutim, u okolnostima stresa koji izaziva pojačana nega i briga oko člana porodice povećava se rizik za stabilnost braka i smanjuje zadovoljstvo životom. Kada porodica nije opterećena dodatnim stresom, poput povećene brige oko člana porodice, bolje slaganje partnera doprinosi zadovoljstvu životom, koje se, pak, sa starošću, praćenom značajnim telesnim i zdravstvenim problemima, umanjuje. Zadovoljstvo životom u obe grupe ispitanika povećava se sa višim nivoom obrazovanja, koji obezbeđuje brojne dobrobiti.

\section{Reference}

Baird, B. M., Lucas, R. E., \& Donnellan, M. B. (2010). Life satisfaction across the lifespan: Findings from two nationally representative panel studies. Social indicators research, 99(2), 183-203.

Batz-Barbarich, C., Tay, L., Kuykendall, L., \& Cheung, H. K. (2018). A meta-analysis of gender differences in subjective well-being: estimating effect sizes and associations with gender inequality. Psychological Science, 29(9), 1491-1503.

Basharpoor, S., \& Sheykholeslami, A. (2015). The relation of marital adjustment and family functions with quality of life in women. Europe's Journal of Psychology, 11(3), 432-441.

Berge, J. M., Patterson, J. M., \& Rueter, M. (2006). Marital satisfaction and mental health of couples with children with chronic health conditions. Families, Systems, \& Health, 24(3), 267-285.

Bešlić, I. i Bešlić, D. (2008). Zadovoljstvo poslom. Škola biznisa, 3, 154-162.

Blanchflower, D. G., \& Oswald, A. J. (2004). Well-being over time in Britain and the USA. Journal of Public Economics, 88(7), 1359-1386.

Botha, F. \& Booysen, F. (2014). Family Functioning and Life Satisfaction and Happiness in South Households. Social Indicators Research, 119(1), 163-182. https://doi. org/10.1007/s11205-013-0485-6

Bratko, D. i Sobil, J. (2006). Osobine ličnosti i osnovne psihološke potrebe kao prediktori zadovoljstva životom: rezultati on line istraživanja. Društvena istraživanja, časopis za opća društvena pitanja, 15(4-5), 84-85.

Chen, C. (2001). Aging and life satisfaction. Social Indicators Research, 54, 57-79.

Cheung, F., \& Lucas, R. E. (2014). Assessing the validity of single-item life satisfaction measures: results from three large samples. Quality of Life Research, 23(10), 2809-2818.

Čekrlija, Đ., Turjačanin, V. i Puhalo, S. (2004). Društvene orijentacije mladih. Banja Luka: Nacionalni institut za borbu protiv narkomanije.

Čudina Obradović, M. i Obradović, J. (2006). Psihologija braka i obitelji. Zagreb: Golden marketing - Tehnička knjiga. 
Ekas, N. V., Lickenbrock, D. M., \& Whitman, T. L. (2010). Optimism, social support, and well-being in mothers of children with autism spectrum disorder. Journal of autism and developmental disorders, 40(10), 1274-1284.

Freund, A. M., \& Baltes, P. B. (1998). Selection, optimization, and compensation as strategies of life management: Correlations with subjective indicators of successful aging. Psychology and Aging, 13, 531-543.

Goldner-Vukov, M. (1988). Porodica u krizi. Beograd: Medicinska knjiga.

George, D., \& Mallery, M. (2010). SPSS for Windows Step by Step: A Simple Guide and Reference, 17.0 update (10a ed.) Boston: Pearson.

Hedrih, V. (2013). Posao i porodica: dosadašnja istraživanja, teorijski pristup i shvatanja. U V. Hedirih, J. Todorović i M. Ristić (Ur.), Odnosi na poslu i u porodici u Srbiji početkom 21. veka (str. 9 -18). Niš: Filozofski fakultet u Nišu.

Krebs, D. (1997). Razvoj altruizma, U S., Joksimović, S. Gašić Pavišić i Lj, Miočinović (Ur.), Vaspitanje i altruizam (str 47 - 56). Beograd: Institut za pedagoška istraživanja.

Mafini, C., \& Dlodlo, N. (2014). The relationship between extrinsic motivation, job satisfaction and life satisfaction amongst employees in a public organisation. SA Journal of Industrial Psychology, 40(1), 01- 12. doi:10.4102/ sajip.v40i1.1166

Mikulincer, M., Shaver, R. Ph., Gillath, O., \& Nitzberg, A.R. (2005). Attachment, Caregiving, and Altruism: Boosting Attachment Security Increases Compassion and Helping, Journal of Personality and Social Psychology, 89(5) 817-839.

Milojković, M., Srna, J. i Mićović, R. (1997). Porodična terapija., Beograd: Centar za brak i porodicu.

Minnotte, K. L., Pedersen, D., \& Mannon, S. E. (2010). The emotional terrain of parenting and marriage: Emotion work and marital satisfaction. The Social Science Journal, 47(4), 747-761.

Mitić, M. (1997). Porodica i stres, između poraza i nade. Beograd: Institut za psihologiju, IP “Žarko Albulj”.

Nikolaev, B. (2018). Does higher education increase hedonic and eudaimonic happiness?. Journal of Happiness Studies, 19(2), 483-504.

Oberle, E., Schonert-Reichl, K. A., \& Zumbo, B. D. (2011). Life satisfaction in early adolescence: Personal, neighborhood, school, family, and peer influences. Journal of youth and adolescence, 40(7), 889-901.

Pallant, J. (2009). SPSS: Priručnik za preživljavanje: postupni vodič kroz analizu podataka pomoću SPSS-a za Windows (verzija 15). Beograd: Mikro knjiga.

Pinquart, M., \& Sörensen, S. (2001). Gender differences in self-concept and psychological well-being in old age: A meta-analysis. The Journals of Gerontology, Series B: Psychological Sciences and Social Sciences, 56, 195-213.

Pinquart, M., \& Sörensen, S. (2003). Differences between caregivers and noncaregivers in psychological health and physical health: A meta-analysis. Psychology and Aging, 18(2), 250-267. https://doi.org/10.1037/0882-7974.18.2.250

Prenda, K. M., \& Lachman, M. E. (2001). Planning for the future: A life management strategy for increasing control and life satisfaction in adulthood. Psychology and Aging, 16, 206-216. 
Raboteg-Šarić, Z. (2002). Skala altruizma. U K. Lacković-Grgin, A. Proroković, V. Ćubela i Z. Penezić (Ur.), Zbirka psihologijskih skala i upitnika, Sv. 1 (str. 87-92). Zadar: Filozofski fakultet u Zadru.

Sari, E. P., \& Dahlia, W. (2018). Family Functioning and Subjective Well.Being among Adolescents. Malaysian Online Journal of Counseling, 5(1), 43-51.

Scorsolini-Comin, F., \& Santos, M. A. (2012). Correlations between subjective well-being, dyadic adjustment and marital satisfaction in Brazilian married people. The Spanish Journal of Psychology, 15(1), 166-176.

Shields, M., \& Wooden, M. (2003). Marriage, children and subjective well-being. Paper presented at the 8th Australian Institute of Family Studies Conference. , Melbourne, Australia. Abstract retrieced from http://www.melbourneinstitute.com/hilda/Biblio/ hbibliocq.html

Spanier, G. B. (1976). Measuring dyadic adjustment: New scales for assessing the quality of marriage and similar dyads. Journal of Marriage and the Family, 15-28.

Sobsey, D. (2004). Marital Stability and Marital Satisfaction in Families of Children with Disabilities: Chicken or Egg?. Developmental Disabilities Bulletin, 32(1), 62-83.

Sousa, L., \& Lyubomirsky, S. (2001). Life satisfaction. In J. Worell (Ed.), Encylopedia of women and gender: Sex similarities and differences and the impact of society on gender (pp. 667-676). San Diego, CA: Academic Press.

Stojiljković, S. (1997). Osetljivost za druge i altruističko ponašanje. U S., Joksimović, S. Gašić Pavišić i Lj, Miočinović (Ur.), Vaspitanje i altruizam (str. 197-210). Beograd: Institut za pedagoška istraživanja.

Unanue, W., Gómez, M. E., Cortez, D., Oyanedel, J. C., \& Mendiburo-Seguel, A. (2017). Revisiting the link between job satisfaction and life satisfaction: The role of basic psychological needs. Frontiers in Psychology, 8, 680. doi: 10.3389/fpsyg.2017.00680

Vajda, D., Thege, B. K., \& Rózsa, S. (2017). Factor structure of the Dyadic Adjustment Scale: A bifactor exploratory structural equation modeling approach. European Journal of Psychological Assessment, 35, 326-334.

Vasić, A., Šarčević, D. i Trogrlić, A. (2011). Zadovoljstvo životom u Srbiji. Primenjena psihologija, 4(2), 151-177. 


\author{
Miljana Spasić Šnele ${ }^{4}$ \\ Jelisaveta Todorović \\ Department of Psychology \\ Faculty of Philosophy \\ University of Niš \\ Niš, Serbia
}

\title{
DIFFERENCES IN THE LIFE SATISFACTION BETWEEN INDIVI- DUALS WHO HAVE AND THOSE WHO DO NOT HAVE FAMILY MEMBER WHO NEEDS SPECIAL CARE
}

\begin{abstract}
Estimation of life satisfaction is an important indicator of mental health. In families where one member needs intensive care and attention, many mental health parameters start to decline, even life satisfaction. In line with that, we conducted research with a goal to explore the role of marriage quality, job satisfaction, altruism, age, education, and gender in life satisfaction in individuals that have a family member in need of intensive care or additional support $(N=98)$ and individuals that who do not have $(N=793)$. The instruments used were the DAS scale, a combination of the Altruism scale and Alzam scale. Life satisfaction and job satisfaction were evaluated on 10-point scale. All participants were married or in a romantic relationship at the time of research. It showed that there is a significant difference in life satisfaction between these two groups of individuals - a lower level of life satisfaction was identified in a group of individuals that has a family member in need of intensive care. Important predictors of life satisfaction in the first group of individuals were job satisfaction and risks for marriage stability, and in the second job satisfaction, partner agreement and age. Life satisfaction is higher among people who have a university degree and/ or higher education than those who have completed high school in both groups. In both groups, job satisfaction represents an important predictor of life satisfaction. Still, we noticed differences when it comes to the quality of marriage - risks of marriage stability decrease life satisfaction in a group that has a family member in need of intensive care, whereas agreement with partner contributes to life satisfaction in the second group of participants.
\end{abstract}

Keywords: life satisfaction, intensive care of a family member, altruism, quality of marriage, job satisfaction

${ }^{4}$ miljana.spasic.snele@filfak.ni.ac.rs 